\title{
SISTEM MANAJEMEN VIRTUAL LOCAL AREA NETWORK (VLAN) PADA CISCO CATALYST 3750 BERBASIS WEB
}

\author{
Astika Ayuningtyas \\ Program Studi Teknik Informatika \\ Sekolah Tinggi Teknologi Adisutjipto \\ Email: astika@stta.ac.id \\ Sudaryanto Sudaryanto \\ Program Studi Teknik Informatika \\ Sekolah Tinggi Teknologi Adisutjipto \\ Email: sudaryanto@stta.ac.id \\ Deno Daseftra Cessara \\ Program Studi Teknik Informatika \\ Sekolah Tinggi Teknologi Adisutjipto \\ Email: daseftra@gmail.com
}

\begin{abstract}
ABSTRAK
VLAN merupakan salah satu teknologi komputer yang saat ini sangat dibutuhkan. Hal ini dikarenakan VLAN dapat membagi satu jaringan pada perangkat switch menjadi bagian-bagian kecil jaringan lain. Cisco Catalyst 3750 merupakan perangkat switch yang sudah menyediakan teknologi VLAN. Permasalahan yang ditemukan pada Cisco Catalyst 3750 adalah sistem manajemen VLAN yang masih berbasis command line dan tidak dapat diakses dari jarak jauh. Untuk itu dibuat VLAN berbasis GUI dan dapat diakses dari jarak jauh. VLAN yang dibuat berbasis Web dengan tujuan untuk memberikan kebebasan pemakaian device dan tidak harus terfokus pada satu jenis device saja. VLAN berbasis Web ini dibuat dengan memanfaatkan API Cisco sebagai penghubung antara bahasa pemrograman pada VLAN berbasis Web dengan bahasa pada perangkat lunak Cisco Catalyst 3750. Pemanfaatan Telnet berperan penting dalam pembuatan VLAN berbasis Web ini, dimana Telnet memberikan akses lebih luas pada Cisco Catalyst 3750 untuk diakses di luar aplikasi terminal emulator. Dengan pemanfaatan Telnet administrator cukup mengujungi IP yang telah dibuat untuk mengakses Cisco Catalyst 3750. Akses jarak jauh pada VLAN berbasis Web ini menggunakan port fowarding. Serveo.net adalah salah satu penyedia layanan port fowarding. Dengan memanfaatkan Serveo.net, VLAN berbasis Web yang masih dalam server local dapat diakses dari jarak jauh meski tanpa IP publik. Hasil pengujian pada penelitian ini menunjukkan bahwa VLAN berbasis Web terbukti dapat melakukan konfigurasi VLAN sehingga dapat digunakan untuk mengatur hubungan antar komputer sesuai dengan kebutuhan pada jaringan yang digunakan.
\end{abstract}

Kata Kunci: VLAN; API cisco; telnet; port fowarding; cisco catalyst 3750.

\begin{abstract}
VLAN is one of the computer technologies that is currently needed. This is because VLAN can divide one network on a switch device into small parts of another network. The Cisco Catalyst 3750 is a switch device that already provides VLAN technology. The problem found on the Cisco Catalyst 3750 is $a$ VLAN management system that is still command line based and cannot be accessed remotely. For this reason, a VLAN based on a graphical interface is created and can be accessed remotely. VLANs are designed from the Web to ensure freedom of use for devices and not just to focus on one type of device. This web-based VLAN is created using Cisco API as a link between programming languages on Webbased VLANs and the language of Cisco Catalyst 3750 software. Using Telnet plays an important role in making this Web VLAN, Telnet offers wider access to Cisco Catalyst 3750 outside of terminal applications emulator. Using the Telnet administrator, just visit the IP address configured to access Cisco Catalyst 3750. Remote access to this Web VLAN uses port forwarding. Serveo.net is one of the port forwarding service providers. Using Serveo.net, web-based VLANs that still exist on local servers can be accessed remotely even without a public IP address. The test results from this study indicate that there is evidence that web-based VLANs are capable of configuring VLANs so that they can be used to manage computer-to-computer relationships based on network requirements used.
\end{abstract}

Keywords: VLAN; API cisco; telnet; port fowarding; cisco catalyst 3750. 


\section{PENDAHULUAN}

Saat ini hampir seluruh kehidupan manusia tidak dapat terlepas dengan teknologi. Banyak teknologi yang bermunculan seiring dengan perkembangan jaman. Salah satu teknologi yang saat ini sedang berkembang pesat adalah teknologi jaringan komputer. Teknologi jaringan komputer saat ini sudah digunakan di berbagai perusahaan, instansi pemerintahan, instansi pendidikan dan lain sebagainya. Kebutuhan akan informasi yang cepat merupakan salah satu penyebab sangat diperlukannya jaringan komputer.

Salah satu bagian jaringan komputer yang saat ini sangat diperlukan adalah Virtual Local Area Network atau disingkat VLAN. Adanya teknik VLAN ini menyebabkan suatu jaringan dapat dibagi menjadi jaringan-jaringan yang lebih kecil dalam satu perangkat yang sama (dikenal dengan switch). Hal ini bertujuan di antaranya mengatasi broadcast domain, keamanan, peningkatan peforma, dan lain sebagainya. Pentingnya sebuah VLAN dalam teknologi jaringan komputer tak terlepas dari manfaat yang telah dibahas diatas. Sehingga administrator jaringan diharuskan mampu melakukan konfigurasi VLAN tersebut.

Sudaryanto [1] dalam penelitian berjudul "The Effect Of Multi Layer Switch For Speed Data Transfer On Computer Network" menjelaskan mengenai Switch Multilayer dan Switch Non Multilayer yang termasuk dalam Switch Manageable. Dalam Switch Non Multilayer fitur yang paling sering digunakan adalah kemampuan switch dalam konfigurasi Virtual LAN (VLAN) dan traffic jaringan yang bisa dikontrol/diatur.

Cisco Catalyst 3750 merupakan salah satu switch non multilayer yang diproduksi oleh Cisco. Konfigurasi VLAN pada Cisco Catalyst 3750 masih berbasis command line, sehingga menuntut administrator jaringan untuk memahami secara keseluruhan perintah-perintah konfigurasi VLAN. Hal ini tentunya tidak mudah dan kurang efisien. Untuk itu dibutuhkan suatu perangkat lunak berbasis GUI yang di dalamnya terdapat perintah-perintah dari konfigurasi VLAN. Perangkat lunak tersebut nantinya akan memudahkan administrator dalam melakukan konfigurasi VLAN.

Pada penelitian Pratama [2] yang berjudul "Konfigurasi Inter-VLAN Pada Cisco Berbasis Graphics User Interface (GUI) Sebagai Pembelajaran Peralatan Jaringan Komputer Cisco" telah berhasil dibuat sebuah perangkat lunak berbasis GUI yang mampu melakukan konfigurasi inter-VLAN, akan tetapi untuk konfigurasi VLAN itu sendiri masih dilakukan dengan basis command line dengan sistem peer to peer menggunakan kabel console. Hal tersebut mengharuskan administrator untuk berada di tempat jika ingin melakukan konfigurasi VLAN. Dengan kata lain konfigurasi VLAN belum dapat dilakukan secara jarak jauh (remote). Keterbatasan penelitian tersebut dalam hal konfigurasi VLAN menjadi dasar dilakukannya penelitian ini, sedangkan perangkat cisco tertentu sudah dibekali dengan teknologi berbasis Web. Pada penelitian ini dibahas khusus mengenai bagaimana membuat VLAN berbasis Web yang dapat melakukan konfigurasi VLAN dari berbagai tempat tanpa harus bersentuhan langsung dengan perangkatnya (switch) dan juga untuk melengkapi teknologi Cisco berbasis web yang belum ada yaitu pembuatan VLAN secara berbarengan (range port) tidak satu persatu serta pembuatan allow trunk secara berbarengan. Diharapkan adanya penelitian ini dapat melengkapi kekurangan yang terdapat pada penelitian sebelumnya.

\section{TINJAUAN PUSTAKA}

Pada penelitian ini terdapat beberapa pustaka yang perlu dipelajari untuk mendukung dalam pembuatan sistem manajemen VLAN. Beberapa pustaka tersebut meliputi Application Programming Interface (API) dan activity diagram untuk mendukung dalam perancangan VLAN berbasis Web.

\subsection{Application Programming Interface (API)}

Menurut Pratama [3] terdapat tiga buah definisi mengenai Application Programming Interface (API), antara lain:

a. API merupakan sekumpulan instruksi yang berada di dua entitas, yaitu entitas yang berjalan di sisi Application Layer dan yang berjalan di sisi sistem operasi.

b. API merupakan kumpulan dari beragam perintah, fungsi, dan protokol di dalam jaringan komputer, yang bekerja sama di dalam menjadikan aplikasi untuk dapat berkomunikasi dengan sistem operasi, perangkat keras komputer, dan komputer lainnya dalam jaringan komputer.

c. API merupakan kombinasi dari beragam perintah dan prosedur yang terurut, sehingga memudahkan di dalam pengembangan perangkat lunak. 


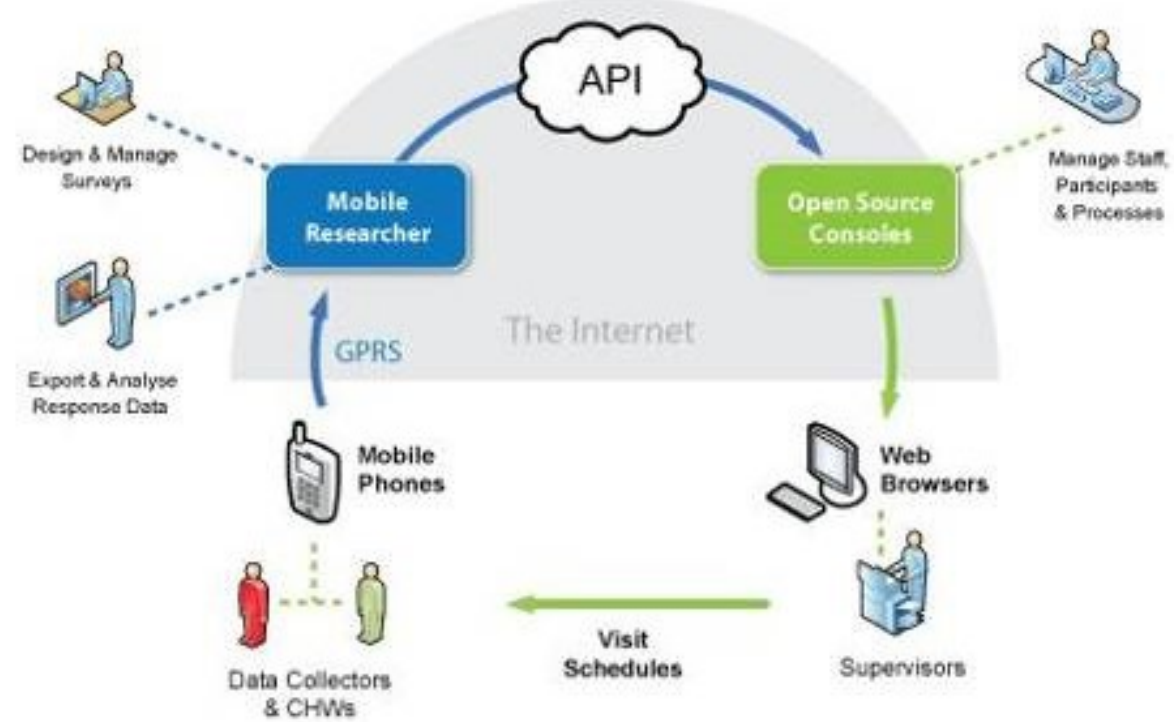

Gambar 1. Konsep API

\subsection{Activity Diagram VLAN Berbasis Web}

Activity diagram "Virtual Local Area Network (VLAN) Berbasis Web Pada Cisco Catalyst 3750 Memanfaatkan Application Programming Interface (API) Dari Cisco" pada Gambar 2 menggambarkan rangkaian aliran dalam sistem. Setelah login berhasil maka akan masuk pada menu utama yaitu Home, Management, Monitoring, Information, Save, dan Logout. Pada menu Management terdapat tiga submenu yaitu: VLAN yang berisi tiga aktivitas (Create, Change, dan Delete), Port yang berisi dua aktivitas (A Port dan Range Port), dan Trunk yang berisi dua aktivitas (Allowed All dan Allowed Range). Pada menu Monitoring juga terdapat tiga submenu yaitu: View VLAN (untuk melihat hasil menu VLAN), View Port (untuk melihat hasil menu Port), dan View Trunk (untuk melihat hasil menu Trunk). Pada menu Information terdapat penjelasan aturan dalam aplikasi ini, sedangkan menu Save untuk menyimpan semua hasil Management dan menu Logout untuk keluar dari menu utama dan kembali pada menu Login. Berikut activity diagram VLAN berbasis Web pada Gambar 2.

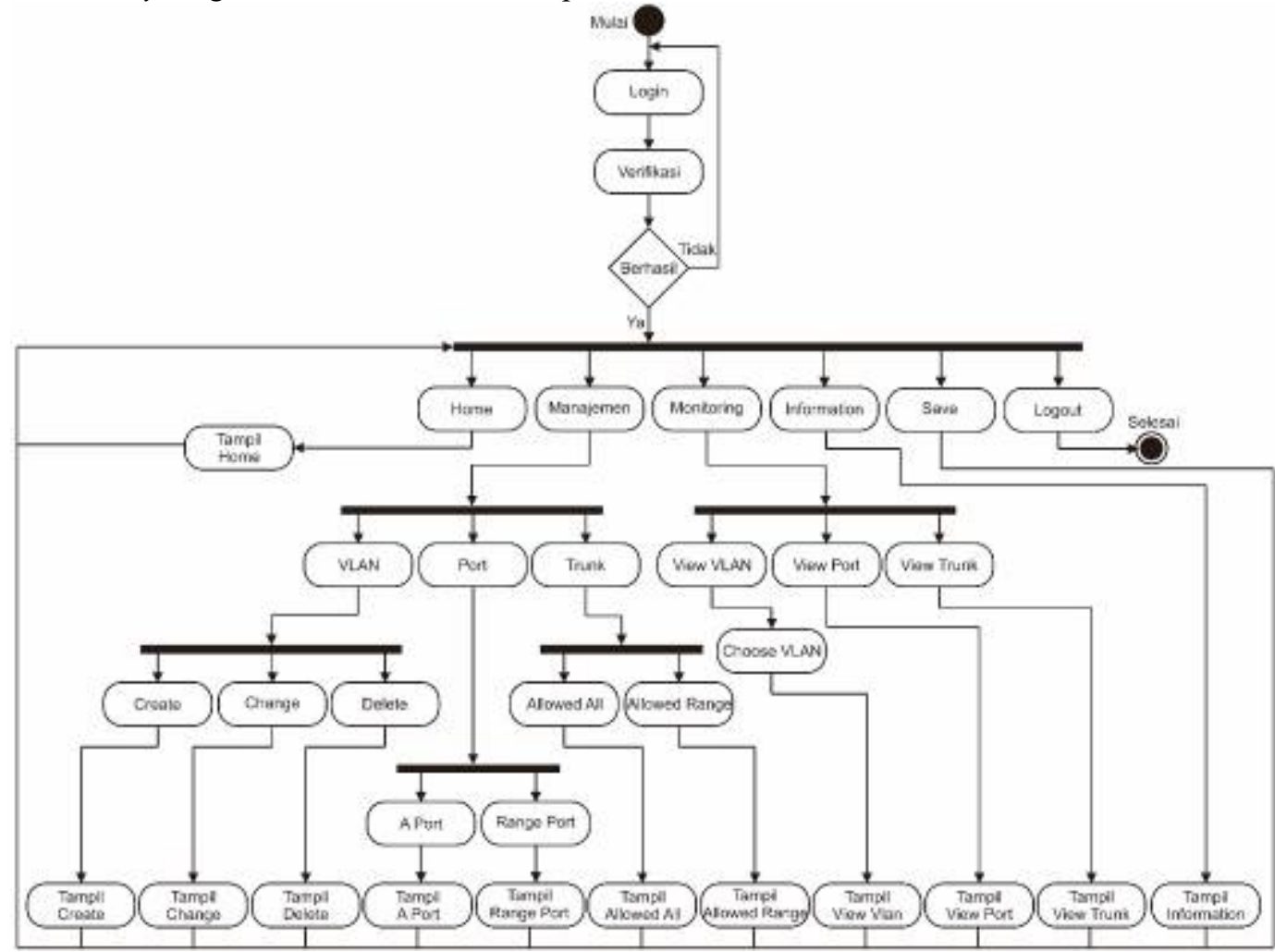

Gambar 2 Activity Diagram VLAN Berbasis Web 


\section{METODE PENELITIAN}

Metode penelitian yang digunakan pada software sistem manajemen VLAN ini menggunakan metode deskriptif yaitu berfokus pada satu kasus secara insentif dan mendetail. Adapun tahapan-tahapan yang dilakukan dalam penelitian antara lain:

\subsection{Pengumpulan Data}

Tahapan ini merupakan tahapan penting untuk mengetahui permasalahan secara lebih lengkap, metode yng digunakan ada dua yaitu yang pertama melalui studi pustaka dengan membaca buku-buku, sumber dari internet baik dari jurnal dan artikel. Selanjutnya untuk metode yang kedua pengumpulan data dilakukan melalui observasi ke bagian laboratorium Sekolah Tinggi Teknologi Adisutjipto Yogyakarta untuk mengamati hal-hal yang diperlukan untuk membuat sistem manajemen VLAN ini.

\subsection{Analisis Proses Berjalan}

Pada tahapan ini dilakukan proses analisa secara keseluruhan berdasarkan data-data yang sudah dikumpulkan melalui tahapan seblumnya untuk kemudian dapat dipelajari dan dipahami tentang proses manajemen VLAN secara keseluruan.

\subsection{Analisis Kebutuhan Sistem}

Setelah dipahami proses secara keseluruhan, tahapan selanjutnya menganalisis kebutuhan-kebutuhan untuk pembuatan sistem seperti kebutuhan jaringan, konfigurasi VLAN dengan memanfaatkan API Cisco, melakukan manajemen VLAN melalui sebuah sistem berbasis Web, pemanfaatan Telnet dalam pembuatan VLAN berbasis Web ini, dimana Telnet memberikan akses lebih luas pada Cisco Catalyst 3750 untuk diakses di luar aplikasi terminal emulator.

\subsection{Perancangan Sistem}

Tahapan ini mulai merancang sistem menajemen VLAN berdasarkan kebutuhan-kebutuhan yang telah dianalisis pada proses sebelumnya.

\section{HASIL DAN PEMBAHASAN}

\subsection{Penjelasan Hasil Rancangan}

Hasil perancangan atau implementasi VLAN berbasis Web dengan screenshoot tiap menu yang ada dapat dilihat pada Gambar 3.

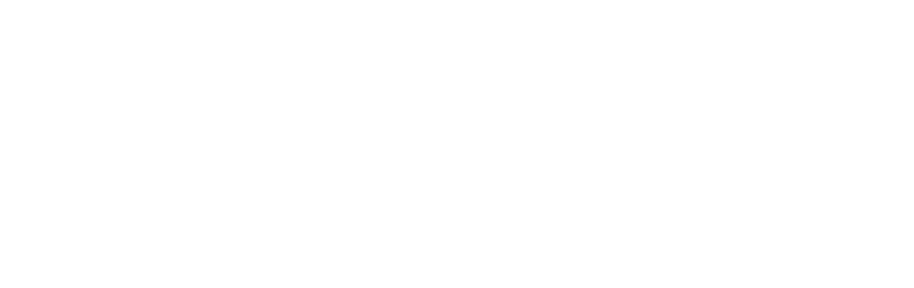


Tabel 1. Perbandingan Sistem Manajemen VLAN dengan Command Line

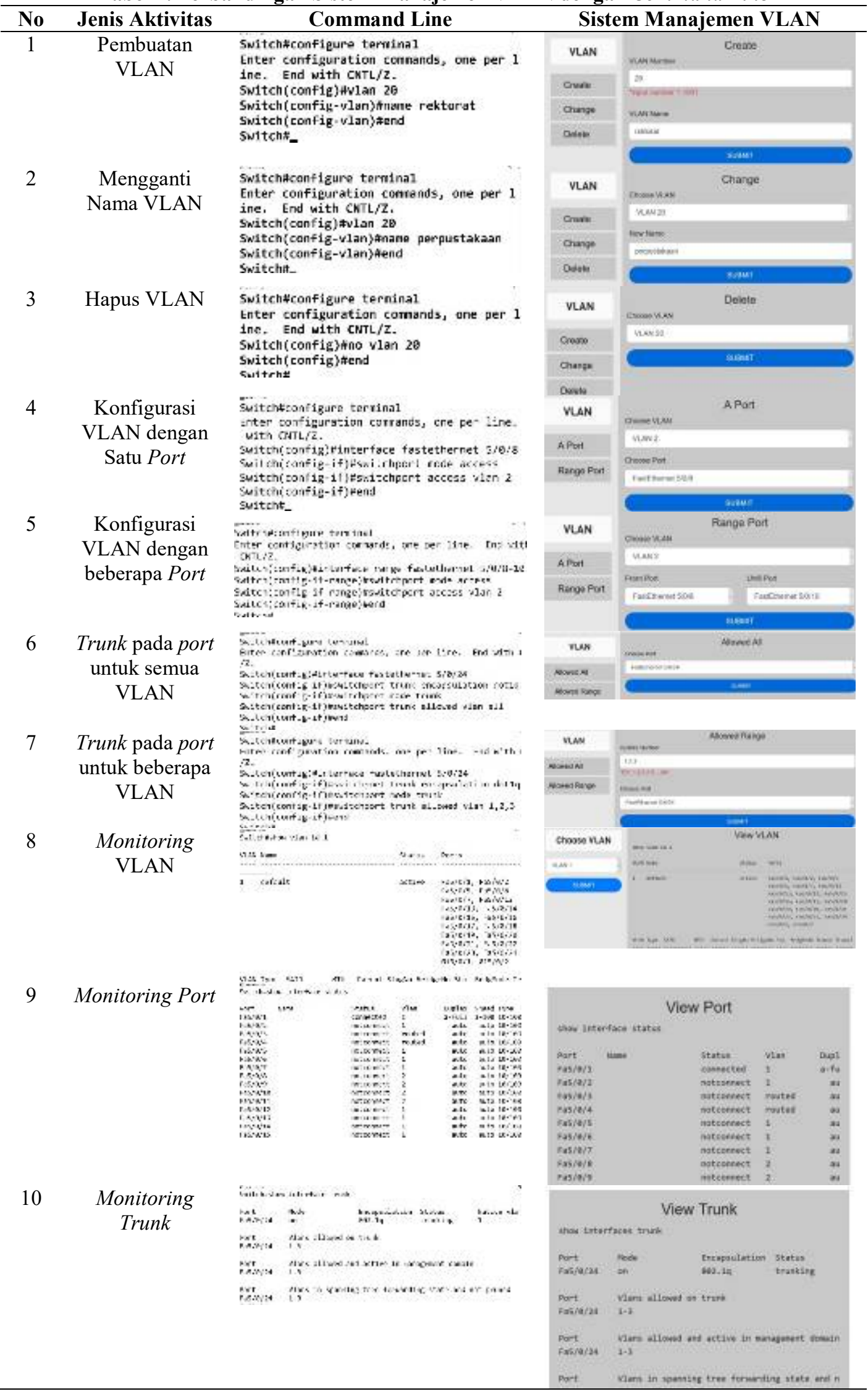




\begin{tabular}{|c|c|c|c|}
\hline No & Jenis Aktivitas & Command Line & Sistem Manajemen VLAN \\
\hline 11 & $\begin{array}{l}\text { Menyimpan } \\
\text { Konfigurasi }\end{array}$ & 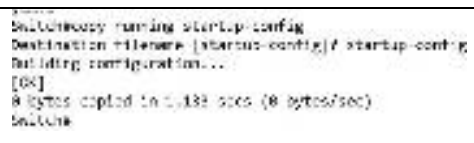 & 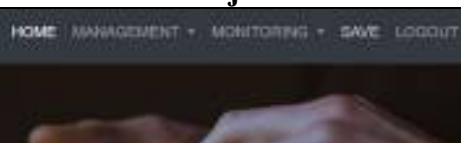 \\
\hline
\end{tabular}

Dari Tabel 1 dapat di simpulkan bahwa aktivitas manajemen maupun monitoring yang biasa dilakukan pada command line dapat dilakukan juga pada Sistem Manajemen VLAN tanpa merubah tujuan dan hasil dari aktivitas tersebut.

\subsection{Pengujian dan Pembahasan}

Pengujian dilakukan dengan cara tes ping pada setiap komputer untuk mengetahui komputer saling terhubung atau tidak. Pengujian dilakukan di laboratorium Sekolah Tinggi Tekologi Adisutjipto seperti pada Gambar 4 dan Gambar 5.

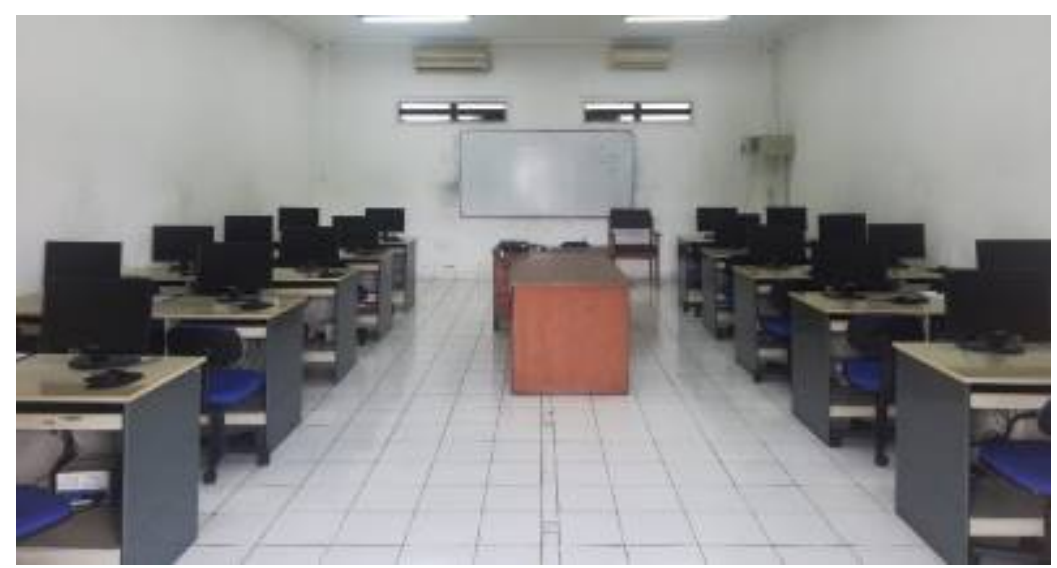

Gambar 4. Laboratorium Komputasi STTA

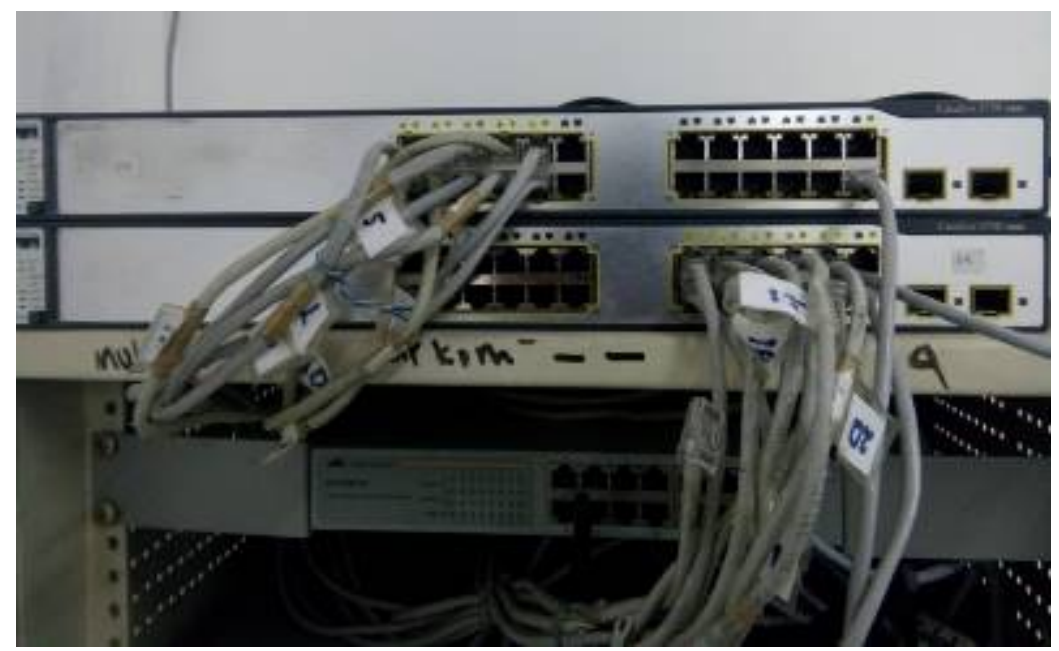

Gambar 5. Switch Cisco Catalyst 3750

\subsubsection{Desain Pengujian dan Konfigurasi VLAN pada Switch}

Pada tahap ini, desain pengujian VLAN dengan konfigurasi yang dilakukan menggunakan SIM VLAN berbasis Web seperti terlihat pada Gambar 6. Untuk pengujian dilakukan dengan cara tes ping pada setiap komputer seperti terlihat pada Gambar 7. 


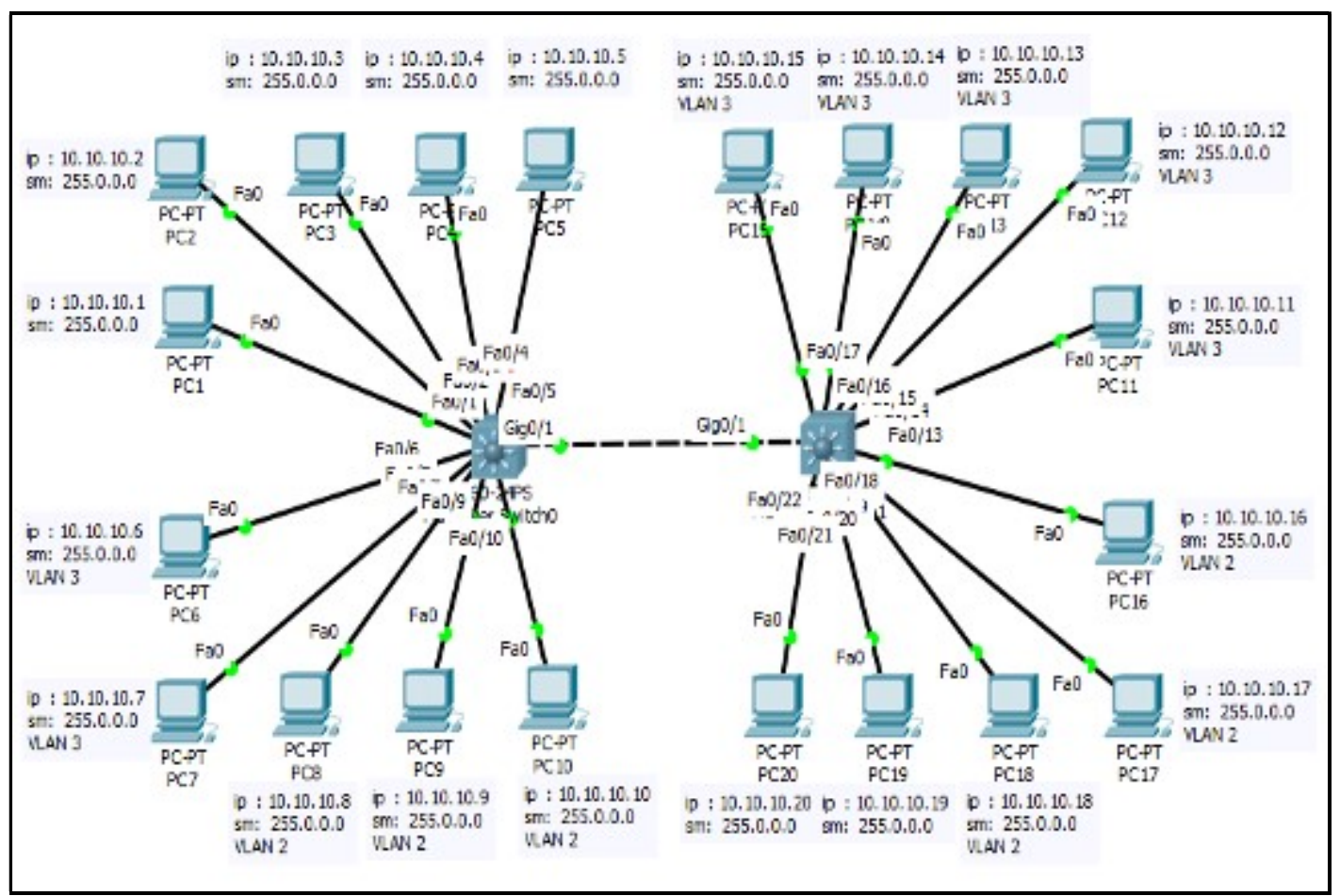

Gambar 6. Desain Vlan pada switch

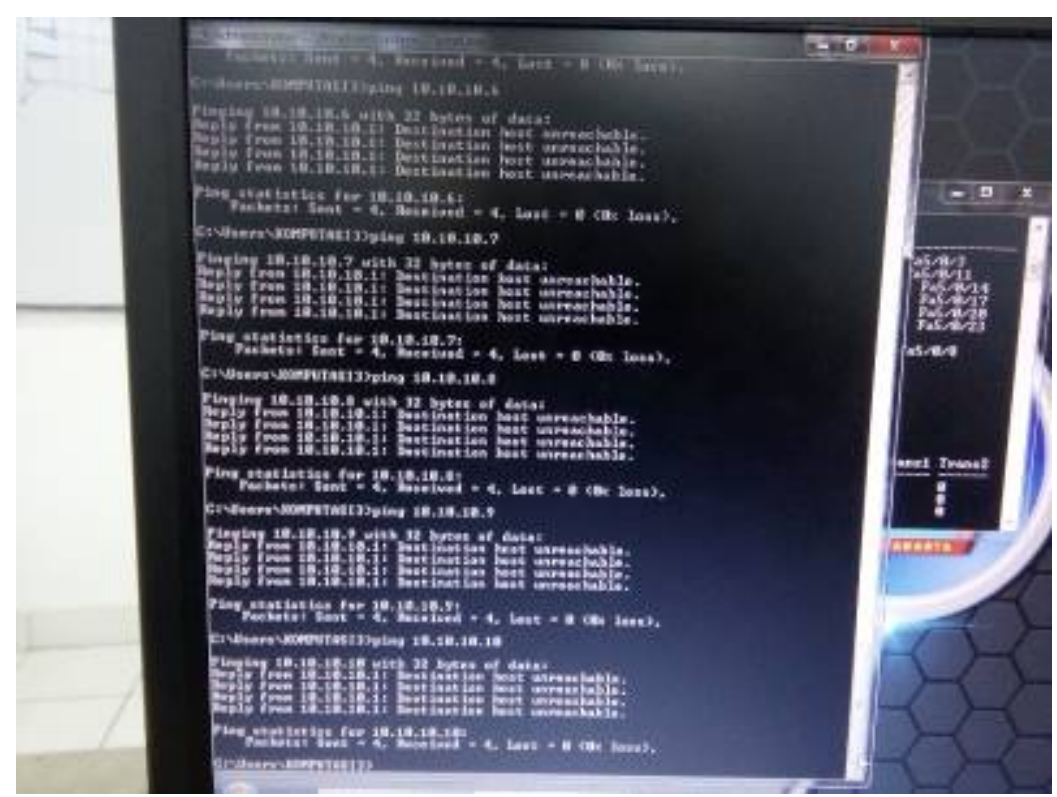

Gambar 7 Tes Ping Antar Komputer

\subsubsection{Uji Coba Tanpa VLAN}

Pada tahap ini dilakukan uji coba ping dari komputer tanpa konfigurasi Vlan terhadap sesama komputer tanpa Vlan dan komputer dengan Vlan baik pada satu switch maupun berbeda switch. Tes ping dilakukan dari komputer 1 seperti terlihat pada Tabel 3 dan prosentasi terhubung atau tidaknya antara satu computer dengan computer yang lainnya diperlihatkan pada Grafik 1 .

Tabel 3. Uji Coba Tanpa VLAN

\begin{tabular}{ccccc}
\hline Dari & Switch & Tujuan & Switch & Hasil \\
\hline Komputer 1 & Switch-0 & Komputer 2 & Switch-0 & Terhubung \\
Komputer 1 & Switch-0 & Komputer 3 & Switch-0 & Terhubung \\
Komputer 1 & Switch-0 & Komputer 4 & Switch-0 & Terhubung \\
\hline
\end{tabular}




\begin{tabular}{ccccc}
\hline Dari & Switch & Tujuan & Switch & Hasil \\
\hline Komputer 1 & Switch-0 & Komputer 5 & Switch-0 & Terhubung \\
Komputer 1 & Switch-0 & Komputer 6 & Switch-0 & Tidak Terhubung \\
Komputer 1 & Switch-0 & Komputer 7 & Switch-0 & Tidak Terhubung \\
Komputer 1 & Switch-0 & Komputer 8 & Switch-0 & Tidak Terhubung \\
Komputer 1 & Switch-0 & Komputer 9 & Switch-0 & Tidak Terhubung \\
Komputer 1 & Switch-0 & Komputer 10 & Switch-0 & Tidak Terhubung \\
Komputer 1 & Switch-0 & Komputer 11 & Switch-1 & Tidak Terhubung \\
Komputer 1 & Switch-0 & Komputer 12 & Switch-1 & Tidak Terhubung \\
Komputer 1 & Switch-0 & Komputer 13 & Switch-1 & Tidak Terhubung \\
Komputer 1 & Switch-0 & Komputer 14 & Switch-1 & Tidak Terhubung \\
Komputer 1 & Switch-0 & Komputer 15 & Switch-1 & Tidak Terhubung \\
Komputer 1 & Switch-0 & Komputer 16 & Switch-1 & Tidak Terhubung \\
Komputer 1 & Switch-0 & Komputer 17 & Switch-1 & Tidak Terhubung \\
Komputer 1 & Switch-0 & Komputer 18 & Switch-1 & Tidak Terhubung \\
Komputer 1 & Switch-0 & Komputer 19 & Switch-1 & Terhubung \\
Komputer 1 & Switch-0 & Komputer 20 & Switch-1 & Terhubung \\
\hline
\end{tabular}

\section{Grafik Pengujian Tanpa VLAN}

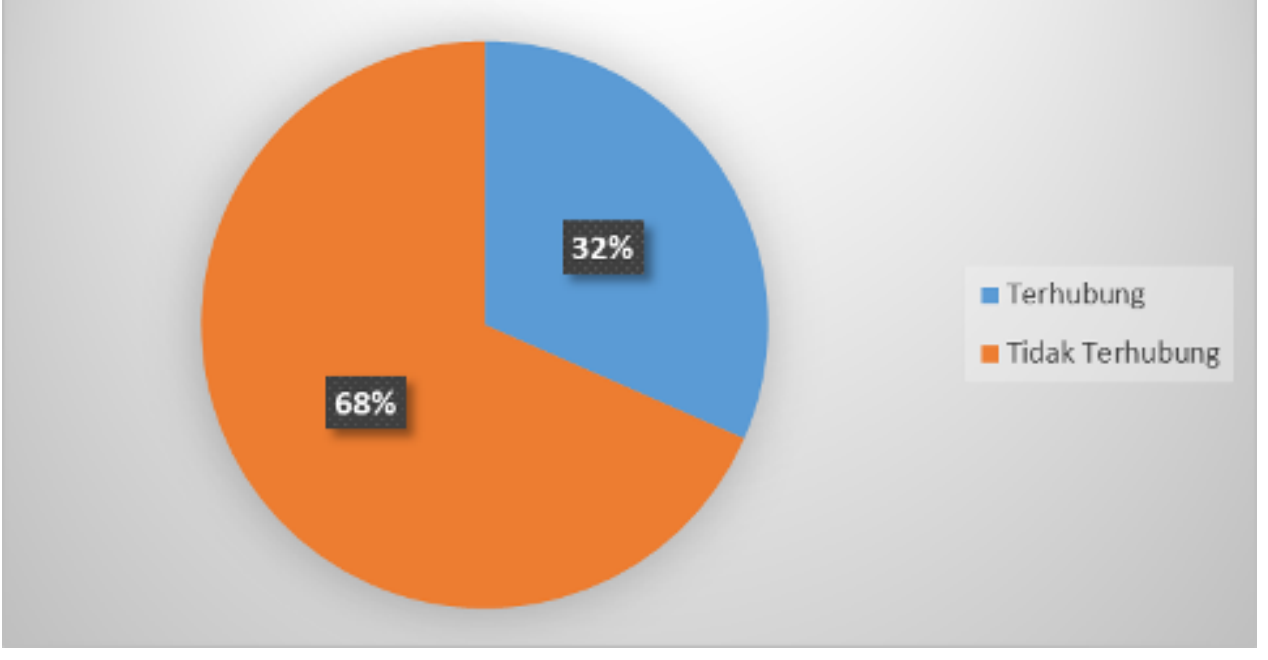

\section{Grafik 1 Grafik Pengujian Tanpa VLAN}

Pada tahap pengujian tanpa VLAN hasil yang didapat pada Tabel 3 menunjukkan bahwa komputer 1 hanya bisa terhubung dengan komputer 2, 3, 4, 5, 19 dan 20 karena ke enam komputer tidak mempunyai konfigurasi VLAN sehingga semua komputer dengan network yang sama akan terhubung sedangkan komputer 1 dengan komputer 6, 7, 8, 9, 10, 11, 12, 13, 14, 15, 16 ,17 dan 18 baik itu dalam satu area switch maupun beda area switch tidak terhubung dikarenakan mempunyai konfigurasi VLAN yang berbeda

\subsubsection{Uji Coba Dengan VLAN}

Pada tahap ini dilakukan uji coba ping dari computer yang mempunyai konfigurasi Vlan terhadap komputer tanpa Vlan, komputer dengan Vlan yang sama dan komputer dengan Vlan yang berbeda baik pada satu switch maupun switch yang berbeda. Tes ping dilakukan dari komputer 6 yang sudah dikonfigurasikan dengan Vlan 3 seperti terlihat pada Tabel 4 dan pada Grafik 2 menunjukan prosentasi terhubung atau tidaknya Antara satu computer dengan computer yang lainnya.

Tabel 5. Uji Coba Dengan VLAN

\begin{tabular}{ccccc}
\hline Dari & Switch & Tujuan & Switch & Hasil \\
\hline Komputer 6 & Switch-0 & Komputer 1 & Switch-0 & Tidak Terhubung (no vlan) \\
Komputer 6 & Switch-0 & Komputer 2 & Switch-0 & Tidak Terhubung (no vlan) \\
Komputer 6 & Switch-0 & Komputer 3 & Switch-0 & Tidak Terhubung (no vlan) \\
\hline
\end{tabular}




\begin{tabular}{ccccc}
\hline Dari & Switch & Tujuan & Switch & Hasil \\
\hline Komputer 6 & Switch-0 & Komputer 4 & Switch-0 & Tidak Terhubung (no vlan) \\
Komputer 6 & Switch-0 & Komputer 5 & Switch-0 & Tidak Terhubung (no vlan) \\
Komputer 6 & Switch-0 & Komputer 7 & Switch-0 & Terhubung \\
Komputer 6 & Switch-0 & Komputer 8 & Switch-0 & Tidak Terhubung (beda vlan) \\
Komputer 6 & Switch-0 & Komputer 9 & Switch-0 & Tidak Terhubung (beda vlan) \\
Komputer 6 & Switch-0 & Komputer 10 & Switch-0 & Tidak Terhubung (beda vlan) \\
Komputer 6 & Switch-0 & Komputer 11 & Switch-1 & Terhubung \\
Komputer 6 & Switch-0 & Komputer 12 & Switch-1 & Terhubung \\
Komputer 6 & Switch-0 & Komputer 13 & Switch-1 & Terhubung \\
Komputer 6 & Switch-0 & Komputer 14 & Switch-1 & Terhubung \\
Komputer 6 & Switch-0 & Komputer 15 & Switch-1 & Terhubung \\
Komputer 6 & Switch-0 & Komputer 16 & Switch-1 & Tidak Terhubung (beda vlan) \\
Komputer 6 & Switch-0 & Komputer 17 & Switch-1 & Tidak Terhubung (beda vlan) \\
Komputer 6 & Switch-0 & Komputer 18 & Switch-1 & Tidak Terhubung (beda vlan) \\
Komputer 6 & Switch-0 & Komputer 19 & Switch-1 & Tidak Terhubung (no vlan) \\
Komputer 6 & Switch-0 & Komputer 20 & Switch-1 & Tidak Terhubung (no vlan) \\
\hline
\end{tabular}

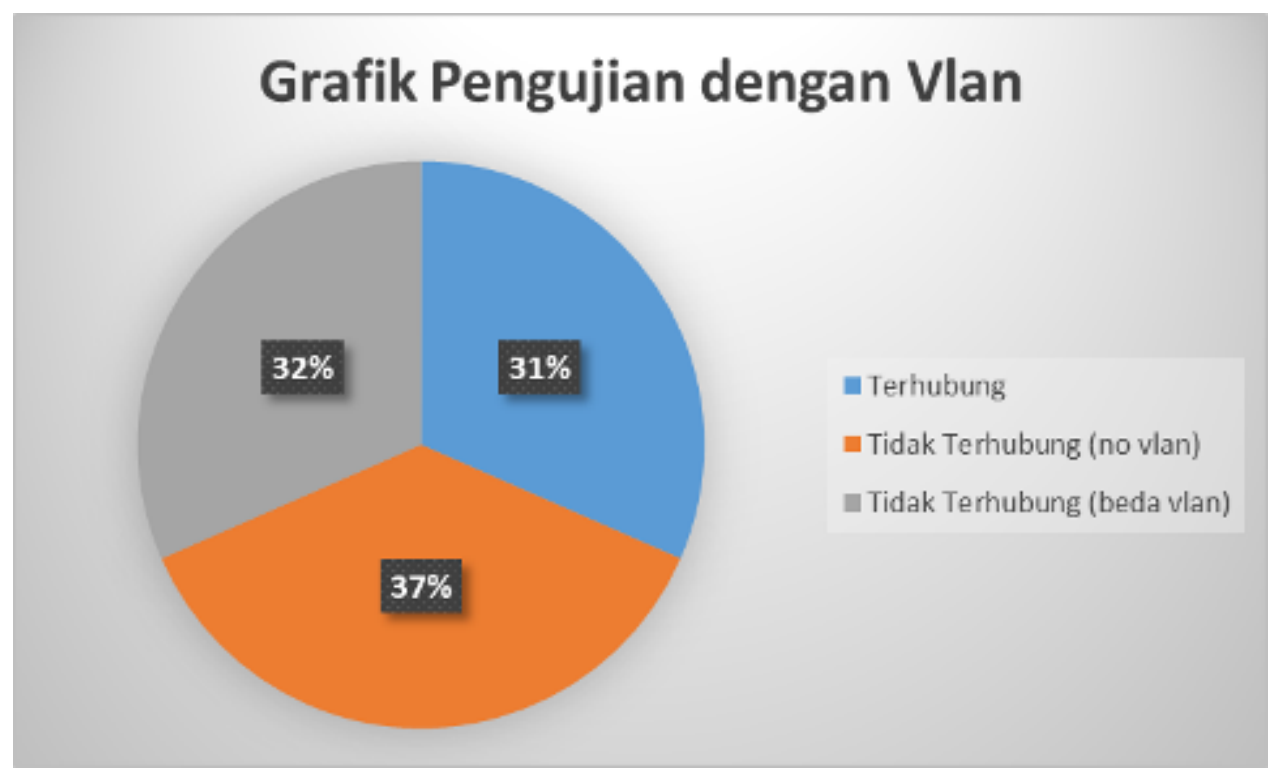

Grafik 1 Grafik Pengujian Dengan VLAN

Pada subbab ini dibahas mengenai hasil yang didapat pada pengujian dengan menggunakan vlan yaitu hasil yang didapat pada Tabel 4 menunjukkan bahwa komputer 6 yang dikonfigurasikan menjadi anggota VLAN 3 tidak dapat terhubung dengan komputer 1, 2, 3, 4, 5, 19, 20 yang belum dikonfigurasikan atau belum diikut sertakan dalam keanggotaan VLAN dan setiap komputer yang berbeda keanggotaan VLAN-nya yaitu komputer 8, 9, 10, 16, 17 dan 18 tidak dapat terhubung sedangkan komputer $7,11,12,13,14,15$ yang keanggotaannya sama VLAN 3 tetap bisa terhubung. Hal ini karena batasan lingkup yang dapat diakses oleh masing-masing VLAN adalah sesama anggota VLAN itu sendiri meski berbeda switch. Perbedaan switch tidak berpengaruh jika di dalam kedua switch tersebut tersedia VLAN yang sama serta seluruh VLAN tersebut diijinkan melewati

Pada percobaan penggunaan aplikasi berbasis web ini dilakukan pada cisco catalyst dengan ios V12.1 dan V12.2 dapat berjalan dengan lancer tanpa ada perubahan script program, sedangkan untuk ios versi yang diatasnya belum dilakukan apakah bisa digunakan atau tidak. Untuk Aplikasi Sistem Manajemen VLAN ini tidak dibuat untuk mewakili semua konfigurasi berbasis command line yang ada pada Catalyst 3750 tetapi dibuat khusus hanya untuk konfigurasi VLAN saja.

\section{KESIMPULAN}

Berdasarkan implementasi dan pembahasan pada "Virtual Local Area Network (VLAN) Berbasis Web Pada Cisco Catalyst 3750 Memanfaatkan Application Programming Interface (API) Dari Cisco" menghasilkan kesimpulan sebagai berikut: 
a) Manajemen VLAN dapat dilakukan dengan berbasis Web menggunakan API Cisco pada Cisco Catalyst 3750 sehingga tidak dibutuhkan lagi command line yang menuntut kemampuan dalam mengendalikan peralatan berbasis teks secara langsung.

b) Manajemen VLAN berbasis Web untuk memanjemen Cisco Catalyst 3750 dapat dilakukan dari jarak jauh (remote) dan jarak dekat dengan syarat ketersediaan jaringan internet dan Web Browser pada alat yang digunakan untuk mengakases.

c) VLAN berbasis Web ini terbukti dapat digunakan untuk membuat membuat VLAN sehingga hubungan antar komputer dengan komputer lainnya bisa diatur sesuai dengan organisasi yang menggunakannya.

\section{DAFTAR PUSTAKA}

[1] Sudaryanto. (2018). The Effect Of Multi Layer Switch For Speed Data Transfer On Computer Network. In Compiler STT Adisutjipto Yogyakarta, 7(2), 85.

[2] Pratama. A. W. (2013). Konfigurasi Inter-VLAN Pada Cisco Berbasis Graphics User Interface (GUI) Sebagai Pembelajaran Peralatan Jaringan Komputer Cisco. In Compiler STT Adisutjipto Yogyakarta, 2(2), 13.

[3] Pratama. I. P. A. E. (2014). Handbook Jaringan Komputer Teori dan Praktik Berbasiskan Open Source. Cetakan Kedua. Informatika. Bandung.

[4] Ross. J. (1997). Internet Power Tools Edisi Indonesia. Dinastindo. Jakarta.

[5] Sofana. I (2014). Cisco CCNA dan Jaringan Komputer. Edisi Revisi. Informatika. Bandung.

[6] (2015). Membangun Jaringan Komputer Mudah Membuat Jaringan Komputer (Wire \& Wireless) untuk Pengguna Windows dan Linux. Cetakan Kedua. Informatika. Bandung.

[7] Sukamto. R.A., M. Shalahudin. (2015). Rekayasa Perangkat Lunak Terstruktur dan Berorientasi Objek. Informatika. Bandung.

[8] Tanenbaum. A.S. (1996). Jaringan Komputer Edisi Bahasa Indonesia Dari Computer Network 3e. Jilid 1. Prenhallindo. Jakarta. 